\title{
Pemikiran Organisasi Islam tentang Penerapan Hukum Pidana Islam: Tinjauan Hukum Hak Asasi Manusia
}

\author{
M. Syafi'ie \\ Fakultas Hukum Universitas Islam Indonesia \\ m.syafie@uii.ac.id
}

\begin{abstract}
This paper elaborates the view of Islamic organizations in Indonesia about the application of Islamic criminal law in the form of cutting off hands, stoning, and whipping, and examining them based on human rights law. The Islamic Organizations whose views are explored here are Nahdlatul Ulama (NU), Muhammadiyah, Indonesian Mujahidin Council (MMI), and Jemaah Anshorut Tauhid (JAT). This article concludes, first, there are two different views of the Islamic Organization studied: one sees its application as a necessity or mandatory, and the other views it as the state responsibility that needs to consider the social interests according to its context. Of the four Islamic organizations studied, the first view was reflected in MMI and JAT, and the second view was on NU and Muhammadiyah. Second, the law of cutting off hands, stoning, and whipping, which for some Islamic organizations is seen as the right to practice worship and belief, cannot be justified by human rights norms. Although the rights to religion and belief are rights that are categorized as non derogable right, the implementation and application of religious teachings is actually categorized as derogable rights. Therefore, for reasons of protection of public security, public order, public health, morals, and fundamental rights and freedoms of others, the application of religious teachings, in this case the punishment for cutting off hands, stoning, and whipping, can be limited.
\end{abstract}

Keywords: Islamic criminal law; human rights; Islamic organization. 


\section{Abstrak}

Artikel ini menguraikan pandangan atau pemikiran organisasi Islam di Indonesia tentang penerapan hukum pidana Islam berupa hukuman potong tangan, rajam, dan cambuk, dan menelaahnya berdasarkan hukum hak asasi manusia. Organisasi Islam yang digali pandangannya di sini adalah Nahdlatul Ulama (NU), Muhammadiyah, Majelis Mujahidin Indonesia (MMI), dan Jemaah Anshorut Tauhid (JAT). Artikel ini menyimpulkan, pertama, ada dua pandangan berbeda dari Organisasi Islam yang diteliti: yang satu memandang pemberlakuannya sebagai keharusan atau wajib, dan yang satu lagi memandangnya sebagai tanggungjawab negara yang perlu mempertimbangkan kepentingan sosial masyarakat sesuai konteksnya. Dari empat Organisasi Islam yang diteliti, pandangan pertama tercermin pada sikap MMI dan JAT, dan pandangan kedua pada NU dan Muhammadiyah. Kedua, hukum potong tangan, rajam, dan cambuk, yang bagi sebagian organisasi Islam dilihat sebagai hak untuk menjalankan ibadah dan keyakinan, tidak dapat dibenarkan oleh norma hak asasi manusia. Sekalipun hak beragama dan berkeyakinan merupakan hak yang terkatagori non derogable right, implementasi dan penerapan ajaran agama sesungguhnya terkatagori derogable rights. Karena itu, dengan alasan perlindungan keamanan publik, ketertiban publik, kesehatan publik, moral, serta hak dan kebebasan fundamental orang lain, maka implementasi ajaran agama, dalam hal ini hukuman potong tangan, rajam, dan cambuk, menjadi bisa dibatasi.

Kata kunci: hukum pidana Islam; hak asasi manusia; organisasi Islam.

\section{A. Pendahuluan}

Artikel ini ingin menggali dan mengidentifikasi pemikiran organisasi Islam di Indonesia tentang penerapan atau pemberlakuan hukum pidana Islam, untuk kemudian menelaahnya berdasarkan hukum hak asasi manusia. Ada empat organisasi Islam yang dilihat respons dan pandangannya tentang penerapan hukum pidana Islam di sini, yaitu Nahdlatul Ulama (NU), Muhammadiyah, Majelis Mujahidin Indonesia (MMI), dan Jemaah Ansorut Tauhid (JAT). Keempat organisasi ini akan dilihat respons dan pandangannya tentang persoalan hukum pidana Islam, dalam hal ini berupa hukuman potong tangan, 
cambuk, dan rajam. Bentuk hukuman yang demikian, sekalipun barangkali dianggap sebagai ekspresi atau manifestasi beragama dan berkeyakinan, dalam implementasinya jelas rentan bersinggungan atau bahkan bertentangan dengan hak asasi manusia.

Di Indonesia, tuntutan pemberlakuan hukum pidana Islam berupa penghukuman potong tangan, rajam, dan cambuk berulang disuarakan dan selalu menjadi polemik. Beberapa Organisasi Islam tegas mengatakan bahwa hukum pidana Islam adalah bagian hukum yang tidak dapat dipisahkan dari perjuangan dan tuntutan menegakkan syariat Islam. Penerapan syariat Islam dinilai bukan berarti anti modernisasi atau menghancurkan hukum modern atau meniadakannya, tetapi pelaksanaan hukum Islam berarti konsekuen terhadap hukum yang berasal dari pembuat hukum tertinggi, yaitu Allah SWT. ${ }^{1}$

Dalam perjalanan Republik Indonesia, tuntutan penerapan syariat Islam, yang di dalamnya termasuk hukum pidana Islam, berlangsung terus-menerus. Sebelum kemerdekaan, tuntutan itu muncul dalam Piagam Jakarta, "Ketuhanan, dengan kewajiban menjalankan syariat Islam bagi pemeluk-pemeluknya”. Teks Piagam ini dalam perkembangannya diubah oleh Mohammad Hatta yang saat itu menjadi Wakil Panitia Persiapan Kemerdekan Indonesia (PPKI), dengan alasan adanya tuntutan dari wakil-wakil Protesan dan Katholik di daerah-daerah yang dikuasai angkatan laut Jepang, yang berkeberatan dengan tujuh kata dalam teks Piagam. ${ }^{2}$

Pasca reformasi 1998, tuntutan penerapan syariat Islam ternyata tidak juga berhenti, bahkan bisa dikatakan semakin membesar diksursus aksi dan diskursusnya. ${ }^{3}$ Di beberapa daerah berlangsung

1 Daud Rasyid, "Kata Pengantar", dalam Topo Santoso, Membumikan Hukum Pidana Islam: Penegakan Syariat dalam Wacana dan Agenda (Jakarta: Gema Insani Press, 2003), hlm. xiii-xiv.

2 Mohamad Roem, "Sejarah Tidak Dapat Dikembalikan”, Kata Pengatar dalam Endang Saifuddin, Wawasan Islam: Pokok-Pokok Pikiran tentang Paradigma dan Sistem Islam (Jakarta: Gema Insani Press, 2004), hlm. xv.

3 Salah satu aksi besar itu misal berlangsung di Jakarta pada 29 Februari 2004, di mana sekitar 20.000 orang pendukung gerakan syariat Islam melakukan long march. Aksi ini diinisiasi oleh Hizbut Tahrir Indonesia (HTI). Baca Kompas, "Hizbut Tahrir Terus Perjuangkan Syariat Islam”, 1/3/2004. 


\section{Syafïe}

seminar dan diskusi tentang syariat Islam, seperti pembahasan tentang perbankan Islam, pemerintahan Islam, pendidikan Islam, sampai dengan hukum pidana Islam. Pada 27 Maret 2001, tokoh Forum Komunikasi Ahlus-sunnah wal Jamaah (FWKT) serta Panglima Laskar Jihad menjatuhkan hukuman rajam terhadap Abdullah, pemerkosa di daerah Ambon, suatu wilayah yang sebagian masyarakatnya dikabarkan telah mendeklarasikan syariat Islam. ${ }^{4}$ Demikian juga hukuman cambuk kepada Zulkarnaen dan Upik, pasangan dari Desa Mata Ie, Blang Pidie, Aceh, karena dinyatakan telah melakukan perzinahan. $^{5}$

Di samping itu, di berbagai daerah bermunculan peraturanperaturan yang bernuansa syariat Islam. Di Tasikmalaya ada Peraturan Daerah (Perda) Nomor 1 Tahun 2000 yang memberi hukuman kepada siapa saja yang menawarkan atau menyediakan diri, menyediakan tempat atau melindungi perbuatan yang tergolong pelacuran dengan ancaman denda maksimal lima juta rupiah serta kurungan paling lama tiga bulan kurungan. ${ }^{6}$ Di Sulawesi Selatan, sebuah Komite Penegakan Penerapan Syariat Islam (KPPPSI) mendesak Dewan Perwakilan Rakyat Daerah (DPRD) untuk menindaklanjuti tuntutan penegakan syariat Islam melalui otonomi khusus. ${ }^{7}$ Di Kalimantan Selatan, pada Musyawarah Besar Pembangunan Banua Banjar (MPBB) di Banjarmasin pada 13-15 Agustus 2000 dan diikuti oleh masyarakt Banjar dari dalam maupun luar negeri, dicetuskan permintaan kepada pemerintah Provinsi untuk melaksanakan syariat Islam. ${ }^{8}$

Perdebatan yang tidak selesai tentang Piagam Jakarta, tuntutan penerapan syariat Islam, ${ }^{9}$ dan munculnya semangat perumusan kebijakan yang serba syariat di beberapa daerah, memperlihatkan dua hal. Pertama, syariat Islam dinilai sebagai bagian yang tidak terpisah dari umat Islam sendiri. Syariat Islam bagi sebagian muslim

4 Adian Husaini, "Secara Konstitusional, Syariah Sudah Berlaku”, Suara Hidayatullah, 02/XIV/2001.

5 Forum Keadilan, No. 7, 20/5/2001.

6 Forum Keadilan, No. 7, 20/5/2001.

7 Forum Keadilan, No. 7, 20/5/2001.

8 Forum Keadilan, No. 7, 20/5/2001.

9 Majalah Forum Keadilan, 39 (2000), hlm. 8-19. 
adalah kewajiban-kewajiban, yang apabila tidak dilaksanakan akan berdampak pada keberimanan dan keberislamannya. ${ }^{10}$ Kedua, tuntutan syariat Islam merupakan media kritik terhadap kebijakan negara yang dinilai belum memenuhi hak-hak pemeluk beragama Islam yang notabene penduduk mayoritas di Indonesia. Setidaknya, tuntutan itu seiring dengan pesan Konstitusi Undang-Undang Dasar Negara Republik Indonesia (UUD NRI) Tahun 1945 yang menjamin hak seseorang untuk beribadat menurut ajaran agama yang diyakininya. ${ }^{11}$ Ketentuan ini diperkuat dengan Pasal $4{ }^{12}$ dan Pasal 22 ayat $1^{13}$ dan $2^{14}$ Undang-Undang Nomor 39 tahun 1999 tentang Hak Aasasi Manusia (UU HAM), serta Pasal 18 ayat $1^{15}$ UU Nomor 12 tahun 2005 tentang Pengesahan International Covenant on Civil and Political Rights.

Oleh karena itu, perlu untuk digali, pertama, bagaimana sebenarnya tuntutan pemberlakuan hukum pidana Islam berupa penghukuman potong tangan, cambuk, dan rajam di internal Organisasi Islam, yang mereka sebut sebagai bagian dari hak beragama dan hak menjalankan ibadah sesuai ajaran agama Islam. Kedua, bagaimana perspektif hukum HAM terhadap penerapan hukum pidana Islam

10 Umat Islam Surakarta (UIS), Surat Ulama Kepada Presiden Ripublik Indonesia 1428/2007M (Surakarta: UIS, 2007), hlm. 69-78.

11 Pasal 28E ayat (1) UUD NRI Tahun 1945: "Setiap orang bebas memeluk agama dan beribadat menurut agamanya ....”.

12 Pasal 4 UU HAM: "Hak untuk hidup, hak untuk tidak disiksa, hak kebebasan pribadi, pikiran dan hati nurani, hak beragama, hak untuk tidak diperbudak, hak untuk diakui sebagai pribadi dan persamaan di hadapan hukum, dan hak untuk tidak dituntut atas dasar hukum yang berlaku surut adalah hak asasi manusia yang tidak dapat dikurangi dalam keadaan apapun dan oleh siapapun".

13 Pasal 22 Ayat 1 UU HAM: "Setiap orang bebas memeluk agamanya masingmasing dan untuk beribadat menurut agamanya dan kepercayaannya itu".

14 Pasal 22 Ayat 1 UU HAM: "Negara menjamin kemerdekaan setiap orang memeluk agamanya dan untuk beribadat menurut agamanya dan kepercayaannya itu”.

15 Pasal 18 ayat 1: "Setiap orang berhak atas kebebasan berpikir, berkeyakinan dan beragama. Hak ini mencakup kebebasan untuk menganut atau menerima suatu agama atau kepercayaan atas pilihannya sendiri, dan kebebasan, baik secara individu maupun bersama-sama dengan orang lain, dan baik di tempat umum atau tertutup, untuk menjalankan agama atau kepercayaannya dalam kegiatan ibadah, ketaatan, pengamalan dan pengajaran". 
berupa potong tangan, cambuk, dan rajam. Kedua persoalan ini dicoba dijawab dan dijelaskan dalam artikel ini.

Dalam membahas pemikiran Organisasi Islam tentang penerapan hukum pidana Islam, artikel ini setelah ini menguraikan terlebih dahulu hak menjalankan syariat dan kebebasan beragam. Uraian ini diperlukan untuk menjelaskan hak beragama dan kebebasan beragama dalam kerangka HAM. Bagian berikutnya membahas ragam tuntutan Organisasi Islam tentang penerapan hukum pidana Islam. Pembahasan bagian ini diawali dengan paparan profil Organisasi Islam yang menjadi sampel penelitian, untuk kemudian dikemukakan pandangan atau, sesuai judul, pemikirannya tentang penerapan hukum pidana Islam. Bagian berikutnya membahas penerapan hukum pidana Islam dalam soal hukum potong tangan, rajam, dan cambuk ditinjau dari hukum HAM.

\section{B. Hak Menjalankan Syariat dan Kebebasan Beragama}

Hak menjalankan syariat Islam dalam tulisan ini menggunakan kerangka teori HAM. Kajian tentang tuntutan penerapan hukum pidana Islam berupa potong tangan, rajam, dan cambuk akan dianalisis dalam perspektif hak beragama dan menjalankan ibadah menurut ajaran agamanya. Dalam penerapan syariat Islam berupa hukum pidana Islam, sesungguhnya tersimpan keyakinan seorang muslim yang notabene domain forum internum. Keyakinan tersebut berdampak pada keinginan untuk melaksanakannya sehingga masuk dalam domain hak forum eksternum. Forum internum dalam hak beragama merupakan hak yang non derogable rights, sedangkan hak menjalankan syariat Islam merupakan forum eksternum, yang dalam beberapa hal bisa dibatasi. ${ }^{16}$

Secara teoretis, HAM pada dasarnya mengatur hubungan individu-individu dengan negara. HAM telah disepakati sebagai hukum internasional yang telah menjadi standar yang kuat bagaimana negara harus memperlakukan individu-individu dalam wilayah yurisdiksinya. HAM memberi jaminan moral dan hukum kepada

16 Lihat ICCPR Pasal 18 (3). 
setiap individu manusia untuk melakukan kontrol dan mendorong aturan dan praktik-praktik kekuasaan yang menghormati HAM, memastikan adanya kebebasan individu dalam berhubungan dengan negara, dan meminta negara untuk melakukan pemenuhan terhadap hak-hak dasar individu dalam wilayah yurisdiksinya. Dalam konteks ini, negara dapat ditegaskan sebagai petugas dan pemangku kewajiban (duty-bearer) untuk menghormati (to respect), melindungi (to protect), dan memenuhi (to fulfill), sedangkan individu-individu yang berdiam dalam wilayah yurisdiksinya adalah sebagai pemangku hak (rights holder) daripada kewajiban dan tanggungjawab negara. ${ }^{17}$

Eksistensi negara sebagai penanggungjawab pemenuhan HAM bisa membawa konsekuensi pada ditetapkannya negara sebagai pihak yang melanggar HAM jika gagal dalam menunaikan tanggung jawabnya. Pelanggaran tersebut bisa diakibatkan karena perbuatannya sendiri (acts by ommision) ataupun kelalaiannya sendiri (act of ommision). Dalam rumusan lain dinyatakan bahwa pelanggaran HAM adalah tindakan atau kelalaian negara terhadap norma yang belum dipidana secara nasional tetapi merupakan norma HAM yang telah diakui secara internasional. Titik tekan pelanggaran HAM ialah pada tanggungjawab negara (state responsibility), bukan individu atau badan hukum lainnya. ${ }^{18}$

Dalam teori hukum HAM, jaminan terhadap HAM terklasifikasi menjadi dua: non derogable rights dan derogable rights. Hak yang terkategori non derogable rights meliputi hak atas hidup, hak bebas dari penyiksaan, hak bebas dari perbudakan, hak bebas dari penahanan karena gagal memenuhi utang, hak bebas dari pemidanaan yang berlaku surut, hak sebagai subyek hukum, dan hak atas kebebasan berpikir, keyakinan dan agama. Sedangkan hak yang terkategori derogable rights meliputi hak atas kebebasan berkumpul, hak atas kebebasan berserikat, hak atas kebebasan menyatakan pendapat,

17 Suparman Marzuki, Politik Hukum Hak Asasi Manusia (Tanpa kota: Penerbit Erlangga, 2014); Jack Donnely, Universal Human Rights in Theory and Practice (Ithaca and London: Cornel University Press, 2003), hlm. 7.

18 Knut D. Asplund, Suparman Marzuki, dan Eko Riyadi (ed.), Hukum Hak Asasi Manusia (Yogyakarta: Pusham UII, 2008), hlm. 68-70. 
berekspresi, mencari dan hak memperoleh inforganisasii. ${ }^{19}$

Selain itu, dalam teori HAM juga dikenal klasifikasi forum internum dan forum eksternum. Forum internum ialah area hak yang terkategori sebagai bagian internal pada diri manusia, meliputi hak kebebabasan pemikiran, keyakinan dan agama. Hak-hak tersebut bergerak dalam area yang internum dan privat, di mana negara dilarang untuk mengintervensi, baik berupa manipulasi, kecurangan, maupun pemaksaan. ${ }^{20}$ Sedangkan forum eksternum merupakan area yang terkategori eksternal, berupa ekspresi, manifestasi yang internal, dan menjadi masuk pada area publik. ${ }^{21}$

Pembahasan tentang kebebasan beragama menjadi masalah HAM yang tertua dan paling kontroversial dan menjadi perhatian internasional sejak munculnya sistem kenegaraan internasional. ${ }^{22}$ Kebebasan beragama sendiri sebenarnya merupakan konsep modern, walaupun secara faktual kebebasan beragama tersebut dapat ditelusuri dalam sejarah panjang peradaban manusia, utamanya ketika hadirnya agama-agama, baik dimensinya agama samawi ataupun non samawi.

Secara umum, inti normatif dari HAM atas kebebasan beragama atau berkeyakinan ada delapan. Pertama, kebebasan internal, yaitu hak atas kebebasan berpikir, berkesadaran, dan beragama untuk memiliki, menganut, mempertahankan atau pindah agama atau keyakinan. Kedua, kebebasan eksternal, yaitu kebebasan, baik sendiri atau bersama-sama dengan oranglain, untuk menjalankan agama atau kepercayaannya dalam kegiatan pengajaran, pengamalan, ibadah, dan penaatan. Ketiga, tanpa dipaksa, yang berarti ketiadaan paksaan

19 Ifdhal Kasim, "Hak Sipil dan Politik: Sebuah Sketsa”, Makalah Pelatihan HAM untuk Jejaring Komisi Yudisial RI, Denpasar, 2010.

20 Manfred Nowak dan Tanja Vospernik, "Pembatasan-Pembatasan yang Diperbolehkan terhadap Kebebasan Beragama atau Berkeyakinan”, dalam Kebebasan Beragama atau Berkeyakinan: Seberapa Jauh?, ed. Tore Lindholm, W. Cole Durham Jr., dan Bahia G. Tahzib-Lie, terj. Rafael Edy Bosko dan M. Rifa'I Abduh (Yogyakarta: Kanisius, 2010), hlm. 204.

21 Natan Lerner, "Sifat dan Standar Minimum Kebebasan Beragama atau Berkeyakinan”, dalam Kebebasan Beragama atau Berkeyakinan, hlm. 177.

22 Malcom D. Evans, Religious Liberty and International Law in Europe (Cambridge: Cambridge University Press, 1997), Bab 2. 
untuk menganut atau menetapkan agama atau keyakinannya sesuai dengan pilihannya. Keempat, tanpa diskriminasi, yang berarti adanya penghormatan dan jaminan oleh negara kepada individu untuk beragama atau berkeyakinan dengan tanpa diskriminasi. Kelima, hak orang tua dan wali, yaitu kebebasan orang tua dan wali untuk memastikan pendidikan agama dan moral anak-anak mereka sesuai dengan keyakinan mereka sendiri. Keenam, kebebasan korporat dan kedudukan hukum, yaitu hak komunitas keagamaan dalam beragama atau berkeyakinan, sehingga manifestasi beragama dan berkeyakinan bukan hanya secara individual saja tetapi juga bersamasama dengan orang lain. Ketujuh, pembatasan yang diperbolehkan terhadap kebebasan eksternal, yaitu oleh ketentuan hukum dan kebutuhan untuk melindungi keamanan publik, ketertiban, kesehatan, moral, atau hak-hak mendasar orang lain. Dan kedelapan, tidak dapat dikurangi, yang berarti negara tidak boleh mengurangi hak kebebasan beragama atau berkeyakinan, bahkan dalam keadaan darurat publik. ${ }^{23}$

Delapan inti normatif HAM dalam kebebasan beragama tersebut merupakan seperangkat norma HAM yang kompleks, saling mendukung dan terkodifikasi secara internasional. Delapan inti norma tersebut juga terkesan tumpang tindih, karena kebebasan beragama satu sisi berlaku untuk individu manusia, tetapi juga berlaku untuk melindungi aktivitas komunitas dan hubungan antar generasi. Hak atas kebebasan beragama menjadi suatu yang kompleks dan mengandung sub-sub elemen yang beragam. Karena itu, kondisi ini mengarah pada kecenderungan untuk menginterpretasikan kebebasan beragama melalui filter konseptual dari norma-norma lain yang terkait dengan sub-sub elemen dari kebebasan beragama, seperti kesetaraan, kebebasan berekpresi dan supremasi hukum. ${ }^{24}$

23 Tore Lindholm, W. Cole Durham Jr., Bahia G. Tahzib-Lie, Nazila Ghanea, dan Neni Indriati Wetlesen, "Pengantar", dalam Kebebasan Beragama atau Berkeyakinan, hlm. 20-21.

24 Lindholm, dkk., "Pengantar", hlm. 20-21. 


\section{Ragam Tuntutan Organisasi Islam terkait Penerapan Hukum Pidana Islam}

Artikel ini memilih empat Organisasi Islam sebagai sampel dalam melihat pandangan atau pemikirannya tentang penerapan hukum pidana Islam, yaitu Majelis Mujahidin Indonesia (MMI), Jemaah Anshorut Tauhid (JAT), Nahdlatul Ulama (NU) dan Muhammadiyah. Keempat Organisasi dipilih karena terlihat memiliki cara pandang yang relatif berbeda dalam memahami konsep dan implementasi syariat Islam di Indonesia, khususnya terkait penerapan hukum pidana Islam berupa hukum potong tangan, rajam, dan cambuk. Keempat Organisasi ini juga relatif memiliki anggota kelompok yang relatif besar dengan persebaran yang cukup luas.

\section{Majelis Mujahidin Indonesia}

Majelis Mujahidin Indonesia (MMI) dideklarasikan pada 7 September 2000 bertepatan dengan Kongres pertamanya yang dilangsungkan di Gedung Mandala Bhakti Wanitatama, Yogyakarta. Kongres pertama MMI dihadiri lebih dari 1.800 peserta yang datang dari varian elemen organisasi Islam dan politik Islam, seperti Laskar Santri, Laskar Jundullah, Komp Badr, Brigade Taliban, Komando Mujahidin dan Partai Keadilan. Dalam Kongres hadir tokoh-tokoh seperti Deliar Noer, Abdurrahman Basalamah, Fuad Amsyari, Mawardi Noer, KH. Abdul Qodir Baraja, Muhammad Thalib, Irfan S. Awwas, dan Abu Bakar Ba'asyir. Dalam kongres tersebut, Abu Bakar Baasyir terpilih sebagai Amir Mujahidin dan Irwan S. Awwas sebagai Ketua Lajnah Tanfidziah.

MMI didirikan dengan visi tathbiqusy Syari'ah yang mempunyai penegakan syariat Islam. Tujuan utama MMI ialah berlakunya syariat Islam melalui kekuatan negara. Para tokoh yang terlibat dalam MMI meyakini bahwa krisis multidimensi yang terjadi di Indonesia hanya dapat teratasi dengan penerapan syariat Islam di semua sektor kehidupan. Legitimasi pelaksanaan syariat Islam sebenarnya telah tertuang dalam Piagam Jakarta yang terumuskan dalam Konstitusi. Karena kemudian tujuh kata dalam Piagam Jakarta dihapuskan, 
maka upaya umat Islam untuk penegakan syariat Islam harus dimulai dari awal lagi. Kongres pertama MMI dirancang untuk itu, yaitu mendorong penegakan syariat Islam secara total. ${ }^{25}$

Terkait penerapan syariat Islam, sebagian tokoh MMI sebenarnya mengakui bahwa di Indonesia secara parsial telah diterapkan syariat Islam dan bahkan sudah berlangsung, seperti adanya UndangUndang Perkawinan, ibadah haji, puasa, zakat dan beberapa ibadah lainnya. Hal itu terbukti dengan pengelolaan zakat yang lewat sebuah badan amil zakat, dan beberapa pelaksanaan ibadah lainnya yang diatur oleh Kementerian Agama. Namun demikian, syariat Islam dipandang belum sepenuhnya dipenuhi oleh negara sehingga butuh penyempurnaan yang terus menerus. ${ }^{26}$

Di antara syariat Islam yang belum dipenuhi negara menurut MMI ialah terkait penerapan hukum pidana Islam. Tidak berselang lama dari perjuangan memasukkan tujuh kata dalam Piagam Jakarta ke dalam Amandemen UUD NRI 1945, MMI merumuskan dan menerbitkan Usulan Undang-Undang Hukum Pidana Ripublik Indoneesia Disesuaikan dengan Syari'ah Islam. ${ }^{27}$ Usulan hukum pidana ini terdiri dari lima bab: Bab I berisi pengertian dan berlakunya hukum pidana dalam perundang-undangan; Bab II berisi tindak pidana dan pertanggungjawaban pidana meliputi tindak pidana, penyertaan, percobaan, jenis kejahatan hudud dan pidana qishash; Bab III berisi tindak pidana dan pemidanaan, meliputi pelaksanaan hukuman, penangguhan hukuman rajam bagi wanita hamil dan menyusui, tata cara penghukuman cambuk, penjelasan irsy; Bab IV berisi peradilan yang meliputi pembuktian, pengakuan lembaga pengadilan, keanggotaan hakim dan kebebasan hakim; dan Bab V berisi penjelasan pemberlakuan UU ini.

Poin penting gagasan hukum pidana Islam oleh MMI tercantum

25 Endang Turmudi dan Reza Sihbudi, Islam dan Radikalisme di Indonesia (Jakarta: LIPI Press, 2005), hlm. 249.

26 Turmudi dan Sihbudi, Islam dan Radikalisme di Indonesia, hlm. 250.

27 Majelis Mujahidin Indonesia, Usulan Undang-undang Hukum Pidana Republik Indonesia Disesuaikan dengan Syari'ah Islam (Yogyakarta: Markaz Pusat Majelis Mujahidin, tanpa tahun). Baca juga Syamsul Rizal Pangabean, "Wahabisme di Indonesia", makalah Diskusi Wahhabisme, 10, 2/ 3 / 2007. 
dalam Bab II yang menguraikan tentang ketentuan-ketentuan tentang hudud, qishash dan ta'zir. Hudud diartikan sebagai kejahatan yang hukumannya ditetapkan oleh al-Quran dan Sunnah (Pasal 4 ayat 1), yang meliputi sariqah, hirabah, zina, qazaf, syurb, dan riddah (Pasal 9). Qishash (dan diyat) didefinisikan sebagai kejahatan yang dikenakan kepada pelaku kejahatan yang menyebabkan kematian manusia atau menyebabkan kecederaan badan (Pasal 29). Kejahatan yang menyebabkan kematian dikategorikan ke dalam tiga jenis: qatlu al-'amd (menyebabkan kematian karena sengaja), qatlu syibhi al-'amd (menyebabkan kematian karena salah sasaran); dan qatlu al-khata' (menyebabkan kematian karena tidak sengaja (Pasal 30). Sementara ta'zir adalah kejahatan di luar hudud dan qishash (Pasal 4 ayat 3).

Berbagai tindak pidana yang dicakup dalam hudud dan qishash juga ditetapkan hukuman yang spesifik. Tindak pidana pencurian atau disebutnya sariqah adalah dihukum potong tangan kanan untuk kejahatan pertama, potong kaki kiri untuk kejahatan kedua, atau dera dan penjara untuk kejahatan ketiga dan berikutnya (pasal 10 ayat 2). Hirabah atau perampokan dihukum bunuh dan disalib jika korban mati dan diambil hartanya, bunuh jika korban dibunuh tanpa mengambil hartanya, potong tangan kanan dan kaki kiri jika harta korban diambil tanpa membunuh atau menciderainya serta ditambah diyat jika korban diciderai dan diambil hartanya, atau diasingkan (Pasal 14). Zina dihukum rajam sampai mati jika pelakunya telah menikah, atau dicambuk 100 kali ditambah pengasingan jika pelakunya belum menikah (Pasal 16). Qazaf dihukum 80 kali cambuk (Pasal 18). Syurb dihukum maksimal 80 kali cambuk atau minimal empat puluh kali cambuk (Pasal 27). Bagi pelaku riddah yang tidak mau bertobat setelah diberi waktu tiga hari dihukum bunuh dan hartanya diambil untuk baitul mal, jika bertobat hukumannya adalah $t a{ }^{\prime} z$ ir (Pasal 28).

Sedangkan untuk tindak pidana qishash, ialah qatlu al-'amd dihukum bunuh, atau diyat jika dimaafkan wali korban (Pasal 3233). Qatlu syibhi al-'amd dihukum diyat dan bisa ditambah dengan hukuman ta'zir (Pasal 35). Qatlu al-khata' dihukum diyat dan bisa ditambah dengan hukuman ta'zir (Pasal 37). Sedangkan kejahatan yang mengakibatkan cedera dihukum dengan pencederaan yang 
sama seperti yang dialami korban. Tetapi, jika persyaratan syariat tidak terpenuhi, pelaku kejahatan membayar 'irsy (tebusan) dan bisa dikenakan hukuman $t a^{\prime} z i r$.

Secara umum menurut Syamsul Rizal, hukum pidana draf usulan MMI merupakan replika dan adopsi secara total kitabkitab fikih klasik dan sistematikanya dibuat menyerupai kodifikasi hukum pidana. Semisal dalam batasan pengertian pada Pasal 1, diyat ditentukan untuk "satu orang Islam laki-laki adalah 100 ekor onta atau 1000 dinar atau 12000 dirham" (ayat 3), bagi "satu orang perempuan adalah 500 dinar atau 6000 dirham" (ayat 4), sementara untuk "satu orang kafir adalah setengah dari diyat orang Islam” (ayat 5). ${ }^{28}$

\section{Jemaah Anshorut Tauhid}

Jemaah Anshorut Tauhid (JAT) didirikan oleh Abu Bakar Ba'asyir pada 27 Juli 2008 yang bermarkas di Gg. Cempaka No. 02A, Jalan Semenromo, Ngruki, Kelurahan Cemani Grogol, Kabupaten Sukoharjo. JAT dideklarasikan pendiriannya pada 17 September 2008 di Bekasi, Jawa Barat. ${ }^{29}$ Organisasi ini merupakan pecahan dari MMI pada saat Abu Bakar Baasyir menjabat sebagai Amirul Mujahidin. Semasa di MMI, Ba'asyir bisa dikatakan sangat terlibat dan sangat getol dalam mendorong penerapan syariat Islam di Indonesia, termasuk dalam memperjuangkan pengesahan Piagam Jakarta yang diajukan ke DPR Pusat. Bagi Ba'asyir, pencoretan tujuh kata dalam Piagam Jakarta merupakan bentuk perampasan, manipulasi, dan pemerkosaan terhadap hak-hak umat Islam, yang notabene merupakan penduduk mayoritas di Indonesia. ${ }^{30}$

Pendirian organisasi JAT dilatarbelakangi oleh perselisihan pandangan yang sangat tajam di internal MMI terkait model kepempinan organisasi yang menghendaki pergantian kepempinan

28 Pangabean, "Wahabisme di Indonesia".

29 Bambang Karsono, Peran Aktivis JAT dalam Kegiatan Terorisme: Studi Kasus JAT dan Jaringan Aceh-Pamulang (Jakarta: Badan Intelijen Negara, 2010), hlm. 52 .

30 Abubakar Ba'asyir, "Seruan ke Arah Tathbiqus Syari'at", dalam Risalah Kongres Mujahidin I dan Penegakan Syariah Islam, ed. Irfan Surhayardi Awwas (Yogyakarta : Wihdah Press, 2001), hlm. 139. 
secara periodik melalui forum kongres atau muktamar. Ba'asyir yang menjabat Amirul Mujahidin tidak sependapat dengan pandangan tersebut, sehingga memilih keluar dan meninggalkan jabatannya pada MMI. Menurut Ba'asyir, Anshorut Tauhid berarti pembela tauhid, sehingga organisasi didirikan untuk berupaya mengembalikan metode kepemimpinan Islam sesuai dengan ajaran Islam. Pemimpin dalam ajaran Islam dipilih oleh Dewan Syuro yang merupakan tokohtokoh pilihan, sementara demokrasi yang menghendaki one man one vote, atau suara rakyat suara Tuhan, dipandang menyamakan suara ulama dengan siapa pun termasuk seorang penjahat atau pelacur. Kebenaran dalam Islam tidak bisa ditentukan oleh suara mayoritas, tetapi oleh ketentuan-ketentuan yang bersifat syar' $i{ }^{31}$

Bagi Ba'asyir, struktur kepemimpinan terletak pada seorang Amir yang memiliki otoritas dan tidak perlu ada pergantian secara periodik selama Amir masih hidup dan mampu melaksanakan amanah jemaah serta tidak melanggar syariat Islam. Sebab, tegaknya ajaran Islam mensyaratkan dua hal yang mendasar, pertama, niat perjuangan wajib ikhlas semata-mata mencari ridha Allah dan keselamatan di akhirat, dan kedua, cara perjuangan wajib benar, yaitu mengikuti petunjuk sunnah. ${ }^{32}$

Terkait tuntutan penerapan syariat Islam dan konteks hukum Islam di Indonesia, JAT menghendaki penerapan syariat Islam secara totalitas. Hal itu terbaca dari salah satu rilis resmi yang dikeluarkan pada 23 Juni 2014 dan ditandatangani oleh Ba'asyir (Amir Jemaah), Firman Taufiquroman (Khatibul 'Aam) dan Fuad Al-Hazimi (Majelis Syariah). Dalam rilis tersebut dinyatakan beberapa hal-hal berikut: ${ }^{33}$ 1. Nasehat kepada kepala negara. Kepala negara adalah hamba

31 Baca Ali Belhaj, Ad-Damghah al-Qowiyah Menghancurkan Demokrasi, terj. Muhammadi Shiddiq Al-Jawi (Bogor : Pustaka Thariqul Izzah, 2002), hlm. 1-10.

32 http:/ / www.ansharuttauhid.com/jamaa h/sistemorganisasi.html.

33 Judul rilis berbunyi: "Jamaah Anshorut Tauhid: Risalah Peringatan dan Nasehat Karena Allah. Dari Jamaah Anshorut Tauhid (JAT) kepada HambaHamba Alloh Terutama Yang Dibebani Amanah Mengatur Bumi Allah Nusantara/Indonesia dan Rakyatnya”. Teks lengkap bisa diunduh pada laman resmi JAT: http:/ / www.ansharuttauhid.com. 
Allah yang dibebani amanah oleh Allah untuk mengatur negara dan rakyatnya. Setiap kepala negara memikul amanah dan akan dimintai pertanggungjawaban oleh Allah. Kelak, yang dimintai pertanggungjawaban adalah amanah Allah dan bukan amanah manusia dan rakyat.

2. Tugas kepala negara. Kepala negara wajib mengatur negara dan rakyatnya menurut perintah dan ketentuan Allah, bukan atas kemauan mayoritas rakyat, karena kebanyakan manusia itu sesat.

3. Cara mengatur negara dan rakyat. Negara dan rakyatnya wajib diatur hanya dengan hukum Allah/Syariat Islam dan Peraturan/ Undang-Undang yang berdasar hukum Allah. Tidak boleh kompromi dengan orang yang menolaknya.

4. Hukum Allah yang diamalkan untuk mengatur negara dan rakyat harus murni, bersih dari campuran/oplosan dengan hukum jahiliyyah dan ideologi-ideologi ciptaan akal manusia.

5. Hukum Allah yang diamalkan untuk mengatur negara dan rakyatnya di samping harus murni juga kaffah (keseluruhan). Maksudnya adalah, tidak boleh satupun hukum ditolak karena dianggap tidak sesuai dengan keadaan lalu diganti dengan undangundang ciptaan akal manusia. Misal, hukum potong tangan bagi pencuri yang memenuhi bukti-bukti untuk dihukum potong tangan diganti dengan penjara karena dinilai tidak manusiawi. Dalam hal ini, negara harus didasari Al-Qur'an dan Sunnah Nabi. KUHP harus sesuai syariat Islam secara murni dan kaffah. Amanat ini merupakan harga mati yang tidak boleh ditawar.

6. Hakekat thaqhut. Thaqhut adalah tiap-tiap yang melampaui batas-batas hukum Allah. Pentolan thaghut antara lain setiap penguasa negara yang menolak mengatur negara dan rakyatnya yang dikuasainya dengan syariat Islam secara murni dan kaffah. Thaghut adalah pelindung dan pemimpinnya orang-orang kafir dan peranannya mengeluarkan rakyatnya dari cahaya hidup (tauhid, iman, akhlaq, dan lain-lain) dan menjerumuskan ke lembah kegelapan hidup (syirik, kafir, munkar, kebobrokan moral, mengikuti hawa nafsu dan lain-lain). 
7. Hakekat Indonesia. Indonesia sejak awal sampai hari ini adalah negara kafir, semua penguasanya yang diberi amanah oleh Allah menolak mengatur negara dengan hukum Allah/Syariat Islam secara murni dan kaffah. Walaupun ada syariat Islam yang diamalkan, tapi dioplos dengan kemusyrikan demokrasi dan kebatilan nasionalisme. Di samping itu, pengamalannya dipotong dengan alasan dinilai tidak sesuai dengan keadaan. Semua penguasa Indonesia sejak awal adalah pentolan thoghut yang berperan menjerumuskan rakyat Indonesia ke neraka. Maka umat Islam yang ingin ibadahnya diterima oleh Allah sehingga selamat nasibnya di akhirat nanti wajib berjuang dengan dakwah dan jihad dengan tujuan merubah agar negara diatur denga hukun Allah secara murni dan kaffah. Maka siapa saja yang menghalangi harus diperangi habis-habisan tanpa kompromi sampai mereka menyerah.

Membaca seruan dan pernyataan sikap organisasi JAT tersebut, tergambar jelas bahwa JAT sangat konkret gagasannya dalam mendorong penerapan syariat Islam secara total, termasuk di dalamnya terkait pemberlakuan hukum pidana Islam berupa penerapan sanksi potong tangan, rajam, dan cambuk. Dalam rilis JAT, tidak dibenarkan sama sekali adanya tafsir penghukuman penjara bagi seorang yang melakukan pencurian. Hukumannya harus sesuai pesan teks Al-Qur'an, yaitu hukum potong tangan.

\section{Nahdlatul Ulama}

Nahdlatul Ulama (NU) berdiri pada 1926, oleh KH. Wahab Hasbullah dan KH. Hasyim Asyari. Kelahiran NU salah satunya merupakan respons atas munculnya gagasan pembaruan Islam di Indonesia yang secara pemikiran banyak dipengaruhi oleh pemikiran Wahabi serta ide-ide pembaharuan Jamaluddin Al-Afgani dan Muhammad Abduh. Di Jawa, gerakan pembaruan dipelopori oleh KH. Ahmad Dahlan, yang pada 1912 membentuk organisasi Muhammadiyah dan banyak mengkritik kelompok muslim tradisional, seperti menolak tarekat, talqin dan tradisi keagamaan tradisional yang dianggap bid'ah dan 
sesat. Akibatnya terjadi ketegangan di internal kelompok Islam di Indonesia. ${ }^{34}$

Sebagai satu organisasi keagamaan yang dari awal menolak cara pandang Wahabi dan memahami Islam secara lebih tradisional, NU tidak ada persoalan dengan bentuk dan ideologi negara Indonesia. Bahkan sejak berdiri NU telah menganggap dirinya adalah satu kesatuan dengan negara Indonesia. Pada muktamar 1935 di Banjarmasin, NU memutuskan Indonesia adalah negara muslim (darul Islam), padahal saat itu dikuasai oleh Belanda. Pemikiran tersebut dilatari oleh pemikiran mayoritas umat Islam di Indonesia diberi kebebasan untuk menjalankan syariat Islam.

Secara umum, pola pemikiran NU yang secara konsisten dijadikan pijakan termasuk dalam melihat dan memperjuangan syariat Islam, meliput empat hal. ${ }^{35}$ Pertama, tawasuth (moderat), yaitu berada di tengah, moderat, dan tidak berada di salah satu titik ekstrem. Prisinsip tawasuth memandu sikap NU untuk tidak terlalu ke kanan atau ke kiri secara ekstrem. Sikap wasathiyyah (moderatisme) menjadi ikhtiar untuk selalu menjadi jalan tengah dari dua kutub yang ekstrem. Pilihan sikap moderat ini akan mendorong NU untuk bersikap akomodatif dan terbuka terhadap berbagai pihak yang saling berselisih paham. ${ }^{36}$

Kedua, prinisp tawazun, yang bermakna seimbang di antara kedua belah pihak, tidak berat atau ringan sebelah. Prinsip ini dalam konteks berhukum dan memperjuangkan syariat Islam selalu menempatkan cara pandang NU untuk proporsional dalam melihat dan menggunakan dalil naqli dan dalil aqli. Prinsip ini didasarkan pada firman Allah, "Sungguh kami telah mengutus rasul-rasul Kami

34 Faisal Ismail, Pijar-pijar Islam: Pergumulan Kultur dan Struktur (Jakarta: Departemen Agama Proyek Peningkatan Kerukunan Hidup Umat Beragama, 1992), hlm. 76-77.

35 Masrur Ahmad MZ, Islam Hijau: Refleksi Keagamaan dan Kebangsaan Nahdlatul Ulama (Yogyakarta: al-Qodir Press, 2014), hlm. 89-100; Abd A’la, Pembaharuan Pesantren (Yogyakarta: Pustaka Pesantren, 2006), hlm. 119129.

36 Said Aqiel Siradj, "Ahlussunnah wal Jama'ah di Awal Abad XXI", dalam Kontroversi Aswaja: Aula Perdebatan dan Reinterpretasi, ed. Imam Baehaqi (Yogyakarta: LKiS, 1999), hlm. 139. 
dengan (membawa) bukti kebenaran yang nyata dan telah Kami turunkan bersama mereka al-Kitab dan neraca (penimbang keadilan) supaya manusia dapat melaksanakan keadilan” (Qs. Al-Hadid : 25).

Ketiga, prinsip tasamuh, yaitu kesediaan diri untuk selalu saling menghargai dalam situasi keragaman dari perbedaan yang ada. Prinsip ini dibangun karena memang secara sosiologis manusia tercipta berbeda-beda dan masyarakat juga berbeda-beda, dan berarti kondisi sosial tidak seragam dan tunggal. Karena itu dibutuhkan kesediaan diri untuk menghormati. Lewat prinsip ini, NU memilih sikap menghindar dari semua kebijakan yang akan melahirkan bentrokan dan benturan. Prinsip ini juga memandu NU untuk bersikap menghargai, menjaga keutuhan umat dan bangsa, serta melestarikan keberagaman (pluralitas) yang ada dalam masyarakat.

Keempat, prinsip amar ma'ruf (mendorng kebaikan) dan nahi munkar (melarang kemunkaran). Prinsip ini mendasarkan pada beberapa perintah Al-Qur'an dan memandu aktivitas dan program NU agar terarahkan pada dukungan terhadap perwujudan segala kemaslahatan kehidupan manusia sekaligus pencegahan terhadap segala tindakan yang destruktif bagi kehidupan umat manusia. Hal ini sejalan dengan firman Allah, "Wahai Anakku, dirikanlah shalat dan perintahkanlah manusia untuk mengerjakan kebaikan dan cegahlah mereka dari perbuatan munkar dan bersabarlah terhadap apa yang menimpa kamu. Sesungguhnya yang demikian itu termasuk hal-hal yang diwajibkan (oleh Allah)" (Qs. Luqman: 17).

Membaca prinsip dan pola pemikiran NU, maka terpahami garis paradigmatik NU terkait tuntutan penerapan syariat Islam di Indonesia, termasuk bagaimana meletakkan hukum pidana Islam seperti potong tangan, rajam dan cambuk. Syariat Islam yang digagas NU adalah Islam ala Indonesia, nusantara, yaitu Islam yang membumi dan dibangun dari nilai-nilai tradisi keindonesiaan. $\mathrm{KH}$. Masrur Ahmad mengatakan bahwa salah satu bentuk Keislaman yang harus dijaga kelestariaannya dan dikembangkan maknanya adalah pola Islam Indonesia. Orang Indonesia tidak harus menjiplak bentuk Islam Arab untuk menjalankan nilai-nilai Islam. Dalam hal pakaian misalnya, orang Islam Indonesia tidak harus memakai jubah supaya 
dikatakan Islam, tetapi cukup memakai sarung, kopiah hitam, dan baju takwa sebagaimana yang berlaku di Indonesia. Hal ini bukan berarti jubah haram, sebab ukuran Keislaman tidak semata diukur dengan bentuk atau pola tertentu. Satu-satunya ukuran keislaman adalah makna dan substansi yang mendasari pola atau bentuk tersebut. $^{37}$

Abdurrahman Wahid (Gus Dur), tokoh penting NU mengatakan tentang pentingnya pribumisasi Islam. Kenyataan di internal muslim, khususnya di Indonesia saat ini ialah tarik menarik yang sangat tajam antara pola keberagamaan yang dibangun dari pola ideal agama (teks) serta pola-pola keberagamaan realitas sejarah (konteks). Islam mesti ditafsirkan secara dinamis dengan mengaitkannya pada beragam tantangan dan tuntutan realitas kemanusiaan. Karena itu, yang dibutuhkan dalam konteks hukum Islam ialah reformulasi yang mengarahkan pada suatu pendekatan multi dimensional untuk merekatkan kembali relevansi ajaran Islam dengan kepentingankepentingan kemaslahatan manusia.

Wajah hukum Islam yang reformulatif tercipta ketika pemaknaan hukum Islam menitikberatkan perhatiannya pada soal-soal duniawi yang melekat dengan persoalan kebangsaan, kenegaraaan, dan kemanusiaan kontemporer. Hukum Islam dituntut untuk mengembangkan diri dalam sebuah proses yang bersifat cair (fluid situation) dan hanya terikat pada gambaran dunia khayal yang menurut teori telah tercipta di masa lampau. Pengembangan diri memerlukan pandangan jauh dari kalangan (hukum) Islam sendiri. Hukum Islam bukanlah suatu produk hukum yangstatis dan ajarannya bukan sesuatu yang sekali jadi sehingga tidak butuh reformulasi dan reaplikasi. Watak hukum Islam selalu membutuhkan penerjemahan secara kontekstual. Ketika konteks historis berubah maka aplikasi prinsip-prinsip internal dari tubuh hukum itupun perlu diubah. ${ }^{38}$

37 Dalam kaitan ini, KH. Musthofa Bisri (Gus Mus) pernah mengatakan bahwa kita adalah orang Indonesia yang beragama Islam, bukan orang Islam yang kebetulan ada di Indonesia. Siradj, "Ahlussunnah wal Jama’ah", hlm. 193194.

38 Ahmad MZ, Islam Hijau, hlm. 207-210. 
Gus Dur secara tegas mengatakan NU berbeda dengan gerakan Islam yang mendukung terhadap formalisasi syariat Islam. Menurut Gus Dur, inti dari pemahaman Keislaman ialah keberpihakan pada kepentingan orang kecil dan segenap persoalannya. Tujuan dari Islam maslahah ammah, yang artinya adalah kesejahteraan umum. Demi kepentingan orang banyak, maka berlakulah kaidah fiqh yang menyatakan bahwa menghindarkan kerusakan atau kerugian diutamakan atas upaya membawa keuntungan atau kebaikan. Ini artinya, menghindari hal-hal yang merusak umat lebih diutamakan atas upaya membawakan kebaikan buat mereka. Cara pandang seperti inilah yang membuat NU (H. Agus Salim dan A. Wahid Hasjim) dan beberapa tokoh Islam lainnya (Ki Bagus Hadikusumo (Muhammadiyah), KH. A Kahar Mudzakkir (Muhammadiyah), Abi Kusno Cokrosuyoso (Sarekat Islam), A. Rahman Baswedan (Partai Arab Indonesia), A. Subardjo (Masyumi), menerima penghapusan tujuh kata dalam Piagam Jakarta. Alasannya adalah agar rakyat Indonesia yang heterogen dalam asal usul mereka dapat bergabung dalam pengakuan negara kesatuan Republik Indonesia. Pilihan tersebut tidak mengundang penolakan dari ulama' fiqh di Indonesia, dan itu berarti bahwa keutuhan dan kesejahteraan umat dinilai begitu tinggi oleh berbagai gerakan Islam. ${ }^{39}$

Lebih spesifik terkait tuntutan perapanan hukum pidana Islam berupa hukum potong tangan, rajam, dan cambuk, KH. Ashari Abta, Ketua Syuriah PWNU Daerah Istimewa Yogyakarta mengatakan bahwa NU tidak aktif mendorong dan meminta penerapannya di Indonesia. Menurutnya, NU lebih banyak aktif mengurus kesejahteraan umat, pendidikan umat dan menjadikan umat sebagai pribadi yang baik. Prioritas NU ialah terkait dengan pemberdayaan umat dan ekonomi kerakyatan. Menurut KH. Ashari Abta, kejahatan yang terjadi di masyarakat sumbernya tidak semata persoalan penghukuman, tetapi juga akibat dari persoalan kemiskinan. Karena itu, mendorong ekonomi kerakyatan menjadi penting dan NU sedang

39 Abdurrahman Wahid, Islamku Islam Anda Islam Kita: Agama Masyarakat Negara Demokrasi (Jakarta: The Wahid Institute, 2006), hlm. 21-23. 
menggarapnya saat ini. ${ }^{40}$

Posisi NU terkait tuntutan penerapan hukum pidana Islam tidak seperti pandangan dan strategi yang disuarakan oleh beberapa gerakan yang menghendaki formalisasi Islam di Indonesia. NU menurutnya memperjuangkan hal-hal yang lebih substantif, khususnya di level pendidikan kemasyarakatan. Kalaupun hukum pidana Islam hendak diberlakukan, prosesnya harus lewat sosialisasi dan penyadaran masyarakat terlebih dahulu. Penetapannya juga mesti lewat jalur demokrasi sehingga nuansa kebersamaan dan kebersatuan tetap terjaga dengan baik. Hukum pidana Islam memang tercantum dengan jelas dalam Al-Qur'an dan Hadist, dan itu menjadi tanggungjawab umat Islam untuk memperjuangkannya, tetapi penerapannya membutuhkan dialog, tahapan-tahapan, dan proses perjuangan yang benar dalam konteks keindonesiaan. ${ }^{41}$

\section{Muhammadiyah}

Muhammadiyah didirikan oleh KH. Ahmad Dahlan di Yogyakarta pada 18 November 1912. Ada beberapa faktor yang melatarbelakangi kelahiran Muhammadiyah, yaitu ${ }^{42}$ pertama, faktor gagasan pembaharuan Islam yang berkembang di Timur Tengah dan mulai diperkenalkan di Indonesia lewat jemaah haji dan bacaan dari penerbitan dan jurnal yang tersebar di kalangan Islam santri di Indonesia. Gagasan pembaharuan Jamal al-Din al-Afghani (1897), Muhammad Abduh (1905), dan Muhammad Rasyid Ridha (1935) mendapatkan respons yang cukup positif dan menjadi bacaan di kalangan umat Islam santri di Indonesia.

Kedua, faktor pembaruan Muhammad Abduh. Gagasan Jamal al-Din al-Afghani dan Muhammad Abduh yang berkembang di Timur Tengah pada abad 19 dinilai menjadi kelanjutan gerakan

40 Wawancara dengan KH. Ashari Abta, Pengasuh Pondok Pesantren Krapyak dan Ketua Mustasyar Pengurus Wilayah Nahdlatul Ulama Daerah Istimewa Yogyakarta, Juli 2012.

41 Wawancara dengan KH. Ashari Abta, Krapyak, Juli 2012.

42 Syarif Hidayatullah, Muhammadiyah dan Pluralitas Agama di Indonesia (Yogyakarta: Pustaka Pelajar, 2010), hlm. 38-42. 
awal pembaharuan paham Wahabi. Pengaruh Abduh cukup kuat dan mempengaruhi Muhammadiyah untuk menerima gagasangagasan dan metode modern. Pandangannya terhadap politik tidak oposisional. Namun demikian, gagasan Abduh dan Muhammadiyah pada dasarnya bersifat keagamaan karena berakar dari Al-Qur'an dan Hadist. Keduanya juga menggalakkan gagasan dibukanya kembali pintu ijtihad, mengecam taqlid dan menjadikan pandangan Ibn Taimiyyah sebagai sumber utama rujukan. ${ }^{43}$

Ketiga, faktor pertentangan internal dalam masyarakat Jawa. Yogyakarta sebagai representasi Jawa dan tempat Ahmad Dahlan adalah pusat kerajaan Mataram Jawa. Ahmad Dahlan yang sebelumnya bernama Darwis lahir dan tumbuh dalam lingkungan yang religius dan dinilai menghadapi ancaman serius terkait tradisi Jawa Hindu. Saat di organisasi Budi Utomo, Dahlan menyaksikan kuatnya Islam sinkretis melalui kebangkitan kebudayaan priyayi. Walaupun Dahlan tercatat sebagai anggota Budi Utomo dan menjadi elite Kraton Yogyakarta pada sisi yang lain, ia merasa tertantang dengan berkembangnya kebudayaan Hindu-Islam dan semangat keagamaannya tergugah untuk bertindak melawan gelombang ini. Perlawanan konkret Dahlan ialah mendirikan organisasi dakwah yang membebaskan Islam Jawa dari campuran adat dan kepercayaan lokal. Organisasi tersebut kemudian diberi nama Muhammadiyah.

Keempat, faktor penetrasi Kristen. Perkembangan kegiatan misi Kristen di Jawa dinilai sebagai muasal lahirnya Muhammadiyah. Keberadaan kolonial Belanda menjadi salah satu sebab dari berkembangnya kristenisasi tersebut. Dahlan dalam beberapa kesempatan mengingatkan umat Islam bahwa apabila mereka tidak bertindak segera dan membiarkan situasi dewasa ini terus berlangsung tanpa melakukan tindakan apapun, maka situasinya akan makin memburuk dan hal itu tidak akan bisa diperbaiki lagi nantinya. Dahlan mengatakan, walaupun Islam tidak akan pernah lenyap dari muka bumi, kemungkinan Islam lenyap di Indonesia tetap terbuka. ${ }^{44}$

43 Alwi Shihab, Membendung Arus: Respon Gerakan Muhammadiyah terhadap Penetrasi Misi Kristen di Indonesia (Bandung: Mizan, 1998), hlm. 132.

44 Shihab, Membendung Arus, hlm. 143. 
Dari latar pendiriannya, terbaca bahwa Muhammadiyah menghendaki pemurnian Islam, melawan sinkretisme Islam, membendung kristenisasi, dan meletakkan Islam sebagai kekuatan yang diperhitungkan dalam konteks pembaruannya yang merujuk pada Al-Qur'an dan Al-Hadist. Menurut Syamsul Arifin, sejak awal pendiriannya, Muhamadiyah dihadapkan pada realitas sosial keagamaan yang kompleks, yaitu, ${ }^{45}$ pertama, persoalan autentisitas dalam paham dan praktik keberagamaan masyarakat Islam. Muhammadiyah melihat banyak paham dan praktik keagamaan yang bercampur-campur dengan tradisi yang berkembang sebelum kedatangan Islam di Nusantara, seperti animisme, dinamisme, kejawen, Hinduisme dan Budhisme. Respons Muhamadiyah terhadap praktik tersebut ialah purifikasi atau memurnikan kembali paham dan keyakinan keberagamaan sesuai sumber autentiknya, yakni AlQur'an dan Hadist.

Kedua, penetrasi kalangan misionaris Kristen yang mendapatkan sokongan dandukungan politik daripenguasa kolonial Belanda. Dalam merespons arus kristenisasi ini, Muhammadiyah melakukan tindakan kompetitif bahkan adaptif, daripada konfrontatif terutama pada masa zaman KH. Ahmad Dahlan. Berbeda dengan organisasi Islam tradisional yang cenderung konservatif terhadap pengelolaan dan modelpendidikan, Muhammadiyahjustrumelakukanadaptasimetode kaum misionaris Kristen dengan melakukan modernisasi pendidikan, baik dalam kelembagaan maupun metode pembelajarannya. Adaptasi kelembagaan ini dilakukan Muhammadiyah di semua sektor, terutama di bidang kesehatan dan keorganisasian. Model pengembangan sosial ini dinilai Muhammadiyah sebagai metodologi yang strategis melawan kristenisasi, yaitu dengan kerja-kerja konkret dalam pembelaan masyarakat lemah sebagaimana perintah Al-Qur'an dan menempatkannya sebagai kerja-kerja yang kompetitif. ${ }^{46}$

45 Edy Suandi Hamid, M. Dasron Hamid, dan Syafri Sairin (ed.), Rekonstruksi Gerakan Muhammadiyah pada Era Multi Peradaban (Yogyakarta: UII Press, 2000, hlm. 74.

46 Baca Muhammadiyah, 100 Tahun Menyinari Negeri (Yogyakarta: Majelis Pustaka dan Inforganisasii Pimpinan Pusat Muhammadiyah, 2013), hlm. 15-18. 
Konteks kelahiran Muhammadiyah dan prinsip ideologi gerakannya sesungguhnya tidak lepas dari organisasi dakwah yang memang menghendaki pemurnian Islam pada satu sisi dan mendorong pembaruan Islam pada sisi yang lain. Sampai saat ini, Muhammadiyah mengalami perkembangan pemikiran yang berarti, yang ditandai dengan munculnya aktivis Muhammadiyah yang terbuka pada wacana pluralitas agama, ${ }^{47}$ hadirnya Majelis Tarjih yang menjadi media pengembangan cara pandang keislaman untuk menjawab persoalan dan tantangan umat Islam kontemporer, dan pengembangan dakwah kultural. Berbeda dengan gerakan pemurnian Islam yang lain, Muhammadiyah menerima ideologi Pancasila sebagai dasar negara Indonesia, baik itu ketika menyusun UUD 1945 maupun ketika pengesahan asas tunggal Pancasila ketika rezim Orde Baru. ${ }^{48}$

Terkait tuntutan penerapan syariat Islam, Muhammadiyah (berbeda dengan gerakan pemurnian Islam lain seperti MMI dan Jemaah Anshorut Tauhid), memilih dua pendekatan sekaligus. Pertama, pemurnian (purifikasi) Islam yang mencakup dua hal, pemurnian tauhid dari semua kemusyrikan dan khurafat-khurafat. Kedua, memurnikan ibadah mahdah dari bid'ah-bid'ah. Pemurnian Islam di sinibisa berdampakpositif dan negatif; positif jika pengikutnya belajar secara tekun Al-Qur'an dan Sunnah, tapi sikap puritan juga berbahaya jika pengikutnya tidak mau belajar dan bingung terhadap obyek yang henak dimurnikan. Kedua, gerakan pembaharuan Muhammadiyah adalah modernisasi, reforganisasii atau ishlah, yaitu menerjemahkan dan mengaktualkan ajaran Islam yang bersifat umum ke dalam kehidupan nyata sesuai dengan konteks zaman. Hal ini biasanya terkait wilayah umum yang bersifat muamalah. Menurut

47 Baca Majelis Tarjih dan Pengembangan Pemikiran Islam Muhammadiyah, Tafsir Tematik Al-Qur'an tentang Hubungan Sosial antar Umat Beragama (Jakarta: Pustaka SM, 2000).

48 Lebih jelas tentang alasan di balik penerimaan Muhammadiyah pada Pancasila sebagai asas tunggal dapat dibaca dalam HM Shaleh Harun dan Abdul Munir Mulkhan, Latar Belakang Umat Islam Menerima Asas Tunggal Pancasila: Sebuah Kajian Informatif Pandangan NU-Muhammadiyah (Yogyakarta: Aquarius, tanpa tahun), hlm. 150-152. 
Yunahar Ilyas, gerakan pemurnian ini akan berbahaya jika dua hal tersebut tidak terjadi sekaligus, sikap pemurnian tidak ada dan pada sisi yang lain modernisasi Islam juga statis. ${ }^{49}$

Cara pandang Muhammadiyah yang memilih modernisasi, reforganisasii atau islah atas ajaran Islam, adalah sikap gerakan pemurnian Islam yang membedakannya dengan MMI, JAT, dan, yang tidak dibahas di sini, Hizbut Tahrir. Cara pandang ini terlihat dari tokoh-tokoh Muhammadiyah dalam melihat dan memperjuangkan tuntutan penerapan syariat Islam, khususnya pemberlakuan hukum pidana Islam berupa hukum potong tangan, rajam, dan cambuk yang tekstual tercantum dengan jelas dalam Al-Qur'an dan Hadist.

Hamim Ilyas, Pengurus Majelis Tarjih Muhammadiyah, mengatakan Muhammadiyah memfokuskan diri pada kerja-kerja sosial seperti pendidikan, kesehatan, kemanusiaan dan kependudukan. Sedangkan untuk hukum, Muhammadiyah tidak aktif. Bagi Muhammadiyah, hukum tidak menjadi wilayah agama, tetapi wilayah tanggungjawab negara, sehingga negara yang punya otoritas membentuk hukum untuk kepentingan rakyatnya. ${ }^{50}$

Hukum potong tangan, rajam, dan cambuk sebagaimana dalam Al-Qur'an itu mestinya tidak dibaca dari segi bentuknya saja, tetapi dikembalikan pada pesan dasar Al-Qur'an, bahwa penghukuman mesti menjadi media rahmatan lil alamin. Penghukuman mesti membawa dampak kebaikan pada masyarakat. karena itu, kalaupun berlaku hukum Islam, ideologinya tetap keadilan. Penyelenggaraan negara hukum juga arahnya pada keadilan sosial, tidak yang lain. Itu yang dipesankan dalam Al-Qur’an.

Hamim mempertanyakan terhadap penerapan perda bernuansa syariah saat ini di beberapa daerah: apakah penerapan hukumhukum itu sudah memenuhi rasa keadilan masyarakat atau tidak. Misalnya di Aceh, di mana seseorang yang melakukan judi akan didera. Sedangkan kalau orang Aceh dan kaya berjudi di Medan, Malaysia, atau Singapura, maka mereka bebas dari hukuman. Dilihat

49 Harun dan Mulkhan, Latar Belakang Umat Menerima Pancasila, hlm. 2-3.

50 Wawancara Hamim Ilyas, Anggota Majelis Tarjih Pengurus Pusat Muhammadiyah, 29/12/2014. 


\section{Syafi'ie}

dari psikologi hukum dan keadilan Islam, hal itu merupakan masalah serius. Hukuman itu hanya berlaku bagi orang-orang kecil saja, masyarakat miskin yang ada di Aceh. Lntas, bagaimana hukuman dera bagi perempuan yang berkhalwat juga ada di Aceh. Kalau perempuan Aceh itu datang ke Jogja atau ke Medan, lalu berkhalwat, apakah perempuan itu didera. Tentu saja tidak. Hukum itu hanya berlaku di Aceh. Belum lagi kemestian mempertimbangkan bahwa khalwat perempuan itu juga akibat pergaulan bebas, liberalisasi pertelevisian dan situasi sosial yang mempengaruhi kehidupan hubungan laki-laki dan perempuan.

Umat Islam menurut Hamim tidak boleh melupakan Umar bin Khattab sebagai bagian dari Sahabat dan diakui Nabi sebagai seseorang yang luas wawasannya. Umar ketika menjadi khalifah tidak mernjadikan Al-Qur'an sebagai kitab Undang-Undang. Dalam tempo yang sangat singkat, sejak meninggalnya Nabi, Umar dalam beberapa kasus tidak memberlakukan hukum potong tangan karena Ia tahu umatnya yang melakukan pencurian adalah akibat dari kondisi kemiskinan. Maka tafsir ayat hudud mesti dimaknai prinsipnya, mencuri memang harus di hukum, tetapi kalau pencurian tersebut akibat kemiskinan, model penghukuman itu mesti dipertimbangkan kembali. Untuk saat ini, hukum potong tangan mungkin tepat, tapi diberlakukan untuk koruptor. Mesti ada tranforganisasii di tengah kondisi sosial yang sudah berubah. Kita tidak bisa melipat bentuk hukum yang berlaku pada 14 abad yang lalu kemudian tanpa pemikiran diterapkan di era saat ini yang sudah berbeda zamannya.

Pandangan umat Islam yang memahami ketentuan hukum pidana Islam $(h u d u d)$ sebagai ayat qoth'i (ayat pasti) mesti dipikirkan kembali, sebab yang qoth'i dalam Al-Qur'an tidak hanya satu ayat, tetapi ada banyak ayat lain yang menjelaskannya. Ayat qoth'i juga sebenarnya bukanlah ayat hukum, melainkan juga ayat tentang rahmat. Al-Qur'an menjadi rahmat bagi kehidupan sosial masyarakat, dan kita mesti tahu bahwa selain hukum, ada dimensi lain yang juga menjadi bagian dari ajaran dan syariat Islam, yaitu aspek ekonomi, budaya, kesejahteraan sosial, dan lainnya. Memahami perintah AlQur'an tidak bisa dengan metode atomistik, satu ayat Al-Qur'an 
dipisah dari ayat-ayat yang lain, melainka mesti memahaminya secara menyuluruh dan tidak sepotong-potong. ${ }^{51}$

Sejalan dengan Hamim Ilyas, mantan Ketua Muhammadiyah Azhar Basyir sepakat dengan ijtihad hukum Umar bin Khattab yang tidak memberlakukan hukum potong tangan bagi pencuri karena adanya unsur subhat yang melingkupinya. Unsur subhat itu ialah adanya keterpaksaan dalam pencurian akibat kemiskinan, bukan akibat dorongan berbuat kejahatan. Dalam pandangan Azhar Basyir, aspek-aspek keadilan sosial menjadi salah satu syarat yang sangat penting dapat diterapkannya hukum potong tangan bagi pencuri. ${ }^{52}$

Azhar Basyir memperlihatkan pandangannya yang bijak dalam melihat pemberlakuan hukum pidana Islam. Baginya, hukum pidana Islam khususnya hukum potong tangan tidak serta merta dilakukan karena telah terjadi pencurian pencurian. Kondisi keadilan sosial masyarakat mesti menjadi pertimbangan fundamental. Apalagi jika mengacu kepada pernyataan Ibn al-Qayyim bahwa pada masa perang, Nabi tidak memberlakukan hukum potong tangan. Sikap Nabi disebabkan adanya shubhat dalam situasi perang. Dalam hal dapat diartikan bahwa hukum potong tangan hanya bisa diterapkan jika kondisi masyarakat telah betul-betul sejahtera dan negara telah memenuhi tanggung jawab ekonomi, sosial dan budaya dengan baik. Karena, dalam kondisi kemakmuran, tidak ada alasan pembenar bagi siapa pun untuk merampas hak-hak orang lain. Jika kondisi sosial masih lemah, kemiskinan masih terjadi dan negara berjalan pada track tanggung jawabnya, maka hukuman hudud mestinya dihindari, sebagaimana pesan Nabi: jangan lakukan penghukuman hudud karena kondisi subhat (idrau' al-hudud bi al-subuhat)..$^{53}$

Uraian pandangan masing-masing organisasi Islam ini menunjukkan, cara pandang MMI, JAT, NU, dan Muhammadiyah memperlihatkan dua jalan berbeda dalam melihat penerapan syariat

51 Wawancara Hamim Ilyas, 29/12/2014.

52 Ahmad Azhar Basyir, "Pokok-Pokok Ijtihad dalam Hukum Islam”, dalam Ijtihad dalam Sorotan, ed. Jalaluddin Rahmat (Bandung: Mizan, 1996), hlm. 59.

53 Ahmad b Hasan al-Baihaqi, Sunan al-Baihaqi al-Kubra (Mekkah: Maktabah Dar al-Baz, 1994), hlm 31. 
Islam, khususnya hukum pidana Islam berupa potong tangan, rajam, dan cambuk. Bagi MMI dan JAT, hukum pidana Islam (hudud) mesti diterapkan di Indonesia, sebab hukum hudud merupakan hak asasi umat Islam dan ketentuannya telah termaktub dalam AlQur'an secara pasti (qoth'i). Salah satu jalan keluar yang ditawarkan adalah mengesahkan kembali tujuh kata dalam Piagam Jakarta dan memberlakukan Rancangan Undang-Undang Hukum Pidana Islam. Jika tidak dipenuhi, MMI dan JAT menilai bahwa pemimpinan negara Indonesia adalah pemimpin thoghut. ${ }^{54}$

Sedangkan bagi NU dan Muhammadiyah, syariat Islam dilihat memiliki dimensi yang luas, meliputi akidah, akhlaq, sosial masyarakat, dan aspek hukum sebagai salah satu cakupannya. Hukum pidana Islam $(h u d u d)$ sendiri adalah bagian dari hukum-hukum Islam yang bahasan dan cakupannya juga banyak. Bagi NU, ketentuan hukum pidana Islam memang tercantum dalam Al-Qur'an, tetapi penerapan hukumnya di Indonesia tidak bisa diberlakukan dengan

54 Menurut JAT, thaghut ialah tiap-tiap yang melampaui batas hukum Alloh. Pentolan thaghut antara lain setiap penguasa negara yang menolak mengatur negara dan rakyatnya yang dikuasainya dengan syariat Islam secara murni dan kaffah. Thaghut adalah pelindung dan pemimpinnya orang-orang kafir dan peranannya mengeluarkan rakyatnya dari cahaya hidup (tauhid, iman, akhlaq mulia dan lain-lain) dan menjerumuskannya ke lembah kegelapan hidup (syirik, kafir, mungkar, kebobrokan moral, mengikuti hawa nafsu dan lain-lain). Namun demikian, pemaknaan thoghut oleh JAT ini dibantah oleh Hamim Ilyas, anggota Majelis Tarjih Muhammadiyah. Menurut Hamim, tafsir JAT terhadap thoghut adalah keliru dan salah dalam mengambil kesimpulan. Umar bin Khattab memaknai thoghut itu sebagai syaitan, ada yang mengatakan maknanya itu dukun (kahin), dan pandangan thoghut yang berkembang saat ini sebenarnya pengambilan kesimpulan dari At-Tabari yang memaknainya sebagai segala sesuatu yang disembah selain Allah. Cara memahami thoghut mestinya memahami Al-Qur'an dengan cara munasabah, yaitu pertautan ayat Al-Qur'an dengan ayat yang lain. Kalau itu dilakukan, maka akan ketemu bahwa thoghut itu berkaitan dengan pengelolaan negara. Dalam hal hukum, tafsir thoghut adalah hukum yang tidak adil. Dalam kaitan negara, tafsir thoghut adalah penyelenggaraan negara yang tidak amanah, tidak memenuhi hak-hak warga negara, dan tidak adil. Cara pandang terkait thoghut ini jangan dilihat dari tafsir atomistik, tetapi mesti ditafsir dengan menggunakan metode munasabah dari satu ayat ke ayat yang lain. Jika tidak, tafsir thoghut akan berbahaya dan keliru dalam memahami persoalan. 
tiba-tiba melainkan dengan proses partisipasi sosial terlebih dahulu. Karena itu, membumikan pesan hukum pidana Islam adalah hal yang sangat penting. Demikian juga bagi Muhammadiyah, hukum pidana Islam dipandang tidak bisa ditafsir secara kaku, karena penerapannya mensyaratkan kemakmuran masyarakat, tanggung jawab negara, dan keadilan sosial pada sisi yang lain. Dengan demikian, bagi NU dan Muhammadiyah, penerapan hukum pidana Islam (hudud) bukanlah suatu tuntutan yang prioritas. Kalaupun hukum pidana Islam hendak diterapkan di Indonesia, mesti ada proses pendiskusian secara partisipatif, adil secara sosial, memberikan dampak kebaikan bagi kehidupan masyarakat dan negara.

\section{E. Tinjauan Norma HAM terkait Hukum Potong Tangan, Rajam, dan Cambuk}

Hukum potong tangan, cambuk, dan rajam adalah bagian dari hukum pidana Islam. Bagi sebagian gerakan Islam, hukum tersebut diletakkan sebagai tuntutan hak asasi manusia. Lebih dari itu, hukum pidana Islam dinilai sebagai kewajiban setiap muslim, sebab hukum tersebut telah diperintahkan dengan jelas oleh Allah SWT dalam AlQur'an dan Hadist. Hukum tersebut bersifat pasti (qoth'i) dan umat Islam yang tidak melakukannya dinilai melanggar hukum Allah, dan kelak akan mendapatkan balasan di akhirat. Karena itu, tuntutan hukum pidana Islam masih terus terjadi sampai saat ini, bahkan di beberapa daerah di Indonesia, salah satunya di Aceh, hukum pidana Islam telah diterapkan.

Sebagai satu tuntutan sosial, dan mendasarkan pada landasan bahwa setiap manusia berhak menjalankan ibadah menurut ajaran agama dan keyakinannya, maka penerapan hukum pidana Islam berupa potong tangan, rajam dan cambuk menjadi penting dibaca sebagai bagian gagasan dan norma hak asasi manusia (HAM) yang berkembang di dunia internasional. Pemerintah Indonesia sendiri telah mengesahkan ragam instrumen hukum HAM. Manfred Nowak dan Tanja Vos Pernik menyatakan, tidak ada keraguan sedikit pun bahwa kebebasan berfikir, nurani, beragama, dan 


\section{Syafi'ie}

berkeyakinan merupakan bagian dari HAM yang paling penting dan bahkan ditempatkan sebagai hak yang tidak boleh diderogasi (dikurangi atau dilanggar dalam kondisi apapun). Pada sisi yang lain, kebebasan beragama dan berkeyakinan melindungi fenomena yang bisa kontroversial dan berbahaya bagi keberadaan manusia, karena agama dan sistem-sistem berkeyakinan ideologis bisa dan bahkan sering disalahgunakan untuk memicu intoleransi, diskriminasi, prasangka, kebencian dan kekerasan. Hak hidup juga bisa terancam dari manifestasi-manifestasi ajaran suatu agama. ${ }^{55}$

Dalam konteks hak beragama dan berkeyakinan, maka akan selalu muncul dua konsep sekaligus, antara forum internum dan forum eksternum. Forum internum ialah ranah internal setiap manusia yang memiliki hak untuk berkeyakinan, berfikir, dan beragama. Dalam hal ini kebebasan tersebut bersifat absolut dan non-derogable rights (tidak dapat dikurangi dalam kondisi apapun. Pada sisi yang lain, hak beragama dan berkeyakinan pasti bertautan dengan realitas sosial. Setiap pribadi beragama pasti akan berinteraksi dengan masyarakat sekitarnya, dan dalam banyak hal dipengaruhi oleh keyakinan agamanya, bahkan menjadi bagian perintah agamanya. Karena itu, hak beragama pasti berkaitan dengan hak untuk menjalankan agama. Itulah yang disebut sebagai forum eksternum, yaitu manifestasi ajaran-ajaran agama. Dalam hal ini, hak menjalankan perintah agama tidak bersifat absolut (derogable rights) dan dapat dibatasi, walaupun pembatasannya tidak boleh sewenang-wenang melainkan harus dengan pertimbangan kepentingan umum dan melalui mekanisme yang demokratis.

Dalam kaitannya dengan kebebasan hak beragama tersebut, negara sebagai pemangku kewajiban menjadi penting untuk hadir dan turut campur menyelesaikan berbagai konflik yang lahir di internal agama, antar agama, dan atau satu agama dengan kepentingan publik secara umum. Pemerintah bisa menjadi aktor kunci dalam menciptakan kebijakan-kebijakan diskriminatif dengan cara memihak secara terang-terangan pada salah satu kelompok agama dan

55 Nowak dan Vospernik, "Pembatasan-Pembatasan yang Diperbolehkan”, hlm. 201-202. 
membantu eksploitasi, tapi bagaimanapun pemerintah pada akhirnya harus mendasarkan kebijakannya pada hukum hak asasi manusia dalam hal membatasi manifestasi agama atau kepercayaan tertentu. ${ }^{56}$

Di Indonesia, pembatasan kebebasan beragama bisa merujuk pada Pasal 28J ayat (2) UUD NRI Tahun 1945: "Dalam menjalankan hak dan kebebasannya, setiap orang wajib tunduk kepada pembatasan yang ditetapkan dengan undang-undang dengan maksud sematamata untuk menjamin pengakuan serta penghormatan atas hak dan kebebasan orang lain dan untuk memenuhi tuntutan yang adil sesuai dengan pertimbangan moral, nilai-nilai agama, keamanan, dan ketertiban umum dalam suatu masyarakat demokratis". Pembatasan juga ditegaskan Pasal 70 UU HAM, "Dalam menjalankan hak dan kebebasannya, setiap orang wajib tunduk kepada pembatasan yang ditetapkan undang-undang dengan maksud untuk menjamin pengakuan serta penghormatan atas hak dan kebebasan orang lain dan untuk memenuhi tuntutan yang adil sesuai dengan pertimbangan moral, keamanan dan ketertiban umum dalam suatu masyarakat demokratis".

Dalam instrumen internasional, pembatasan HAM dapat dilihat pada Pasal 29 ayat (2) Deklarasi Universal HAM, "Dalam menjalankan hak dan kebebasannya, setiap orang tunduk hanya pada pembatasanpembatasan yang ditetapkan oleh hukum dengan maksud sematamata untuk menjamin pengakuan serta penghormatan yang layak terhadap hak dan kebebasan-kebebasan orang lain, dan untuk memenuhi syarat-syarat yang adil dalam hal kesusilaan, ketertiban dan kesejahteraan umum dalam suatu masyarakat yang demokratis". Pasal 18 ayat (1) Kovenan Hak-hak Sipil dan Politik ${ }^{57}$ juga mengatur pembatasan: "Setiap orang berhak atas kebebasan berfikir, berkeyakinan, dan beragama. Hak ini mencakup kebebasan untuk menganut atau menetapkan agama atau kepercayaan atas pilihannya sendiri, dan

56 Nowak dan Vospernik, “Pembatasan-Pembatasan yang Diperbolehkan”, hlm. 201-202.

57 Kovenan ini sudah diratifikasi Indonesia melalui Undang-Undang Nomor 12 Tahun 2005 tentang Pengesahan Kovenan Internasional tentang Hakhak Sipil dan Politik (28/10/2005). 
kebebasan baik secara sendiri maupun bersama-sama dengan orang lain, baik di tempat umum atau tertutup, untuk menjalankan agama dan kepercayaannya dalam kegiatan ibadah, penaatan, pengamalan, dan pengajaran”. Demikian pula pada ayat (2), "Tidak seorang pun dapat dipaksa sehingga terganggu kebebasannya untukmenganutatau menetapkan agama atau kepercayaannya sesuai dengan pilihannya”. Dalam konteks pembatasan, Pasal 18 ayat (3) Kovenan Hak Sipil dan Politik mengatur: "Kebebasan menjalankan agama atau kepercayaan seseorang hanya dapat dibatasi oleh ketentuan berdasarkan hukum, dan yang diperlukan untuk melindungi keamanan, ketertiban, kesehatan, atau moral masyarakat, atau hak dan kebebasan mendasar orang lain”.

Berbagai pembatasan tersebut menunjukkan tidak ada HAM yang benar-benar absolut. Suatu hak dan kebebasan mesti mempertimbangkan hak-hak orang lain, pertimbangan sosial, dan bagaimana negara juga memberi batasan terhadap hak-hak tersebut lewat hukum yang dibuat secara demokratis. Deklarasi Universal HAM sendiri lewat Pasal 29 ayat (2) menyatakan bahwa setiap orang mempunyai kewajiban terhadap masyarakat tempat satu-satunya ia memperoleh kesempatan untuk mengembangkan pribadinya secara penuh dan leluasa.

Menurut Manfred Nowak, pembatasan terhadap manifestasimanifestasi agama bagaimanapun tidak boleh dilakukan dengan sewenang-wenang. Pembatasan tersebut hanya dibenarkan apabila melewati proses dan mekanisme yang benar. Misal, pembatasan oleh hukum mesti ada ditetapkan dalam suatu undang-undang parlementer yang abstrak dan umum atau norma-norma yang sejenis dan dapat dengan mudah diakses dan cukup rinci sehingga orang dapat memperkirakan aplikasi pembatasannya.

Demikian juga jika pembatasan HAM dilakukan karena salah satu dari lima alasan telah ditentukan, yaitu alasan keselamatan umum, moral publik, tatanan/ketertiban masyarakat, perlindungan hak serta kebebasan orang lain dan atau pembatasan memang perlu atau diharuskan (necessary), maka pembatasan tersebut mensyaratkan kehidupan sosial yang demokratis. Artinya, pembatasan tersebut 
mesti proporsional dan dibuat untuk merespons suatu kebutuhan sosial yang mendesak. Sebagai aturan yang bersifat umum, batasanbatasan tersebut akan diinterpretasikan secara sempit dan tentu tidak boleh diskriminatif.

Setidaknya terdapat lima penjelasan dasar-dasar untuk pembatasan legislatif. ${ }^{58}$ Pertama, pembatasan demi perlindungan keamanan publik. Tujuan dari klausul ini ialah memungkinkannya diberlakukan pembatasan-pembatasan terhadap manifestasi agama dalam ranah publik, seperti pertemuan keagamaan, prosesi keagamaan, acara pemakaman, dan beberapa lainnya karena dinilai adanya bahaya tertentu yang akan muncul dan mengancam keselamatan harta benda. Hal ini penting khususnya ketika kelompok keagamaan bermusuhan dan berkonfrontasi satu sama lain. Pada kebanyakan kasus, pemerintah biasanya akan menggunakan klausul keselamatan publik sebagai dasar dan menjadi salah satu upaya untuk melindungi keselamatan invidual orang-orang yang terkena akibat pembatasan tersebut.

Kedua, pembatasan untuk melindungi tatanan/ketertiban publik. Tatanan publik di sini dapat ditafsirkan secara sempit dalam arti pencegahan terhadap kekacauan publik. Dalam konteks ini, peraturan cara berpakaian yang melarang mengenakan penutup kepala bagi perempuan dan gadis Islam, membiarkan jenggot tumbuh lebat bagi kaum Budhis, atau mengenakan sorban bagi kaum Sikh, tidak dapat dijustifikasi sebagai dasarklausul tatanan publik. Termasuk pembatasan lain yang diizinkan terhadap kebebasan memanifestaikan agama seseorang demi kepentingan tatanan/ketertiban publik ialah keharusan bagi komunitas keagamaan untuk didaftar sebagai entitas legal berdasarkan hukum domestik dan untuk menaati perundangundangan umum yang mengatur pertemuan-pertemuan publik atau pendirian tempat-tempat peribadatan publik. Namun demikian, jika peraturan umum tersebut digunakan dengan cara sewenangwenang atau diskriminatif terhadap kelompok keagamaan tertentu, maka kebijakan tersebut dapat dikatagorikan sebagai pelanggaran

58 Nowak dan Vospernik, "Pembatasan-Pembatasan yang Diperbolehkan", hlm. 207-231. 
kebebasan beragama.

Ketiga, pembatasan dalam rangka perlindungan kesehatan publik. Pembatasan ini diperbolehkan karena alasan kesehatan publik terutama dimaksudkan untuk mengizinkan intervensi negara dalam rangka mencegah wabah atau penyakit lain. Ketika tindakan negara merupakan keharusan seperti tugas vaksinasi demi kesehatan publik, dalam hal ini demi kesehatan orang-orang lain, keyakinan keagamaan yang berlawanan dengan tindakan tersebut bisa dibatasi.

Keempat, pembatasan dalam rangka perlindungan moral. Moral merupakan hal yang paling tidak jelas dan paling kontroversial dari semua alasan justifikasi pembatasan kebebasan manifestasi kebebasan beragama. Sebagaimana ditekankan Komite HAM, "konsep moral diderivasikan dari banyak tradisi sosial, filosofis dan agama; akibatnya, pembatasan terhadap manifestasi agama atau keyakinan demi kepentingan moral harus didasarkan pada prinsipprinsip yang tidak hanya berasal dari tradisi tunggal. ${ }^{59}$ Pada sisi yang lain, di tengah ketiadaan suatu standar moral yang seragam secara universal dan regional, maka negara mempunyai batasan penilaian (suatu diskresi) yang cukup luas ketika memberlakukan pembatasan-pembatasan berdasarkan alasan moral. Sebagai contoh, penyembelihan hewan ritual, di mana pemerintah Vorarlverg telah mengemukakan bahwa perlindungan binatang merupakan suatu justifikasi moral untuk melarang penyembelihan domba tanpa pembiusan terlebih dahulu. Dalam perkembangannya, Pengadilan Konstitusi Austria menegaskan bahwa tradisi Yahudi dan Islam kuno dalam penyebelihan dan pengorbanan domba dalam kenyataannya harus lebih mengutamakan nilai-nilai moral perlindungan binatang dari kemungkinan penderitaan yang tidak perlu. Contoh ini merupakan salah satu ilustrasi betapa sukarnya menyeimbangkan antara nilai keagamaan dan nilai moral. Namun demikian, jika seandainya suatu kelompok keagamaan akan memulai lagi dengan mengorbankan manusia, negara pasti mempunyai hak dan kewajiban untuk campur tangan demi perlindungan hak atas kehidupan. Tidak

59 Lihat Komentar Umum 22, pragraf 8. 
ada sistem modern yang menoleransi pengorbanan jiwa manusia untuk kepentingan ritual keagamaan.

Kelima, pembatasan demi melindungi hak dan kebebasan fundamental orang-orang lain. Pembatasan dalam hal ini meliputi beberapa hal, yaitu, pertama, penyebaran agama secara tidak patut (proselytism). Setiap agama pasti punya tendensi inheren utuk berinteraksi dengan agama lain, kadang dalam kasus tertentu mengganggu kebebasan agama orang lain. Dalam hal ini, negara dengan proporsi yang ada penting untuk melakukan intervensi terhadap kebebasan memanifestasikan agama demi melindungi kebebasan beragama orang lain. Kedua, penghujatan (blasphemy) di beberapa tempat dikatagorikan sebagai tindak pidana. Di Yunani, delik proselytism ditujukan untuk melindungi kebebasan keyakinan, agama atau kepercayaan dari kemungkinan aktivitas penyebaran agama secara tidak patut oleh kelompok agama lain. Dengan melakukan penghukuman terhadap proselytisme, maka negara sebenarnya telah melakukan intervensi terhadap kebebasan individu dalam memanifestasikan agamanya melalui kegiatankegiatan misioner demi melindungi kebebasan keagamaan orang lain agar tidak berpindah agama. Pada sisi yang lain, negara dalam hal ini jelas melakukan intervensi terhadap kebebasan berekspresi demi melindungi perasaan keagamaan dan moral, dan tidak mesti kebebasan beragama. Ketiga, hak-hak dan kebebasan-kebebasan selebihnya dari orang-orang lain. Dalam hal ini, tidak diragukan lagi bahwa negara bisa dan terkadang bahkan wajib untuk membatasi manifestasi agama atau keyakinan yang membahayakan hak-hak fundamental orang lain, khususnya hak atas hidup, kebebasan integritas, ruang pribadi, perkawinan, harta kekayaan, kesehatan, pendidikan, kesetaraan, larangan perbudakan serta penyiksaan dan juga hak-hak minoritas. ${ }^{60}$

Dari bahasan alasan pembatasan-pembatasan manifestasi hak beragama tersebut, satu hal yang tidak kalah penting dan berkaitan erat dengan kebebasan berfikir, nurani, dan agama ialah sikap Komite

60 Tentang kebebasan fundamental, bisa dilihat dalam Kovenan Hak Sipil dan Politik (ICCPR) Pasal 18 ayat (3). 
HAMyangmenekankan persamaandannon diskriminasi. Pembatasan oleh negara terhadap manifestasi agama atau keyakinan seseorang hanya dibolehkan jika pembatasan tersebut tidak diskriminatif. Prinsip non-diskriminasi ini penting untuk dikemukakan mengingat hanya sedikit pemerintah yang benar-benar netral ketika berhadapan dengan komunitas keagamaan yang beragam dan aktif di negara tertentu.

Dengan demikian, hak untuk menerapkan hukum pidana Islam sebagai manifestasi dari hak-hak beragama umat Islam, sebagaimana yang menjadi tuntutan sebagian Organisasi Islam, tidak serta dapat diterapkan. Mesti ada mekanisme pertimbangan dan pengujian di ruang publik, pembacaan terhadap dimensi hak orang lain yang hidup di Indonesia, dan desain penghukuman pun harus bersifat manusiawi, tidak menyiksa dan meletakkan hak hidup sebagai salah satu pertimbangan fundamentalnya.

\section{F. Kesimpulan}

Artikel ini menyimpulkan, pertama, ada dua pemikiran atau pandangan berbeda dari Organisasi Islam yang diteliti di sini. Pada satu sisi ada Organisasi yang menilai tuntutan pemberlakuan hukum pidana Islam berupa potong tangan, rajam, dan cambuk bersifat wajib, sedangkan pada sisi lain juga diketahui ada Organisasi yang memaknai syariat Islam sebagai aturan yang digunakan untuk menjabarkan prinsip-prinsip fundamental ajaran Islam sesuai dengan konteks ruang dan waktu, sehingga penerapannya tidak lebih sebagai tanggungjawab negara dengan mempertimbangkan kepentingan sosial masyarakat di Indonesia. Pandangan pertama merujuk pada Majelis Mujahidin Indonesia (MMI) dan Jemaah Anshorut Tauhid (JAT), sedangkan pemikiran atau pandangan kedua diwakili NU dan Muhammadiyah. Kedua, hukum potong tangan, rajam, dan cambuk, yang bagi sebagian organisasi Islam dilihat sebagai hak untuk menjalankan ibadah dan keyakinan, tidak dapat dibenarkan oleh norma HAM. Memang benar bahwa hak beragama dan berkeyakinan merupakan hak yang terkatagori non derogable right, tetapi implementasi dan 
penerapan ajaran agama terkatagori derogable rights. Implementasi ajaran agama bisa dibatasi dengan alasan perlindungan keamanan publik, ketertiban publik, kesehatan publik, moral, serta hak dan kebebabasan fundamental orang lain. Pada aspek yang lain, hukum potong tangan, rajam, dan cambuk, secara substantif bertentangan dengan Konvensi Menentang Penyiksaan dan Perlakuan atau Penghukuman Lain yang Kejam, Tidak Manusiawi dan Merendahkan Martabat Manusia.

\section{Daftar Pustaka}

\section{Artikel/Buku/Laporan}

Ahmad MZ, Masrur. Islam Hijau: Refleksi Keagamaan dan Kebangsaan Nahdlatul Ulama. Yogyakarta: al-Qodir Press, 2014.

A'la, Abd. Pembaharuan Pesantren. Yogyakarta: Pustaka Pesantren, 2006.

Al-Baihaqi, Ahmad Hasan. Sunan al-Baihaqi al-Kubra. Mekkah: Maktabah Dar al-Baz, 1994.

Asplund, Knut D., Suparman Marzuki, dan Eko Riyadi (ed.). Hukum Hak Asasi Manusia. Yogyakarta: Pusham UII, 2008.

Basyir, Ahmad Azhar. "Pokok-Pokok Ijtihad dalam Hukum Islam".

Dalam Ijtihad dalam Sorotan, diedit oleh Jalaluddin Rahmat (Bandung: Mizan, 1996).

Ba'asyir, Abubakar. "Seruan ke Arah Tathbiqus Syari'at”. Dalam

Risalah Kongres Mujahidin I dan Penegakan Syariah Islam, diedit oleh Irfan Surhayardi Awwas. Yogyakarta: Wihdah Press, 2001.

Belhaj, Ali. Ad-Damghah al-Qowiyah Menghancurkan Demokrasi.

Terjemah oleh Muhammadi Shiddiq Al-Jawi. Bogor : Pustaka Thariqul Izzah, 2002.

Donnely, Jack. Universal Human Rights in Theory and Practice. Ithaca and London: Cornel University Press, 2003.

Evans, Malcom D. Religious Liberty and International Law in Europe. Cambridge: Cambridge University Press, 1997.

Forum Keadilan. No. 7, 20/5/2001.

Hamid, Edy Suandi, M. Dasron Hamid, dan Syafri Sairin (ed.). 
Rekonstruksi Gerakan Muhammadiyah pada Era Multi Peradaban. Yogyakarta: UII Press, 2000.

Harun, HM Shaleh dan Abdul Munir Mulkhan. Latar Belakang Umat Islam Menerima Asas Tunggal Pancasila: Sebuah Kajian Informatif Pandangan NU-Muhammadiyah. Yogyakarta: Aquarius, tanpa tahun.

Hidayatullah, Syarif. Muhammadiyah dan Pluralitas Agama di Indonesia.

Yogyakarta: Pustaka Pelajar, 2010.

Husaini, Adian. "Secara Konstitusional, Syariah Sudah Berlaku". Suara Hidayatullah, 02/XIV/2001.

Http: / / www.ansharuttauhid.com/jamaah/ sistemorganisasi.html. Indonesia, Majelis Mujahidin. Usulan Undang-undang Hukum Pidana Republik Indonesia Disesuaikan dengan Syari'ah Islam. Yogyakarta: Markaz Pusat Majelis Mujahidin, tanpa tahun.

Ismail, Faisal. Pijar-pijar Islam: Pergumulan Kultur dan Struktur. Jakarta:

Departemen Agama Proyek Peningkatan Kerukunan Hidup Umat Beragama, 1992.

Karsono, Bambang. Peran Aktivis JAT Dalam Kegiatan Terorisme; Studi Kasus JAT dan Jaringan Aceh-Pamulang. Jakarta: Badan Intelijen Negara, 2010.

Kasim, Ifdhal. "Hak Sipil dan Politik: Sebuah Sketsa”. Makalah Pelatihan HAM untuk Jejaring Komisi Yudisial RI, Denpasar, 2010.

Kompas. "Hizbut Tahrir Terus Perjuangkan Syariat Islam". $1 / 3 / 2004$.

Lerner, Natan. "Sifat danStandar Minimum Kebebasan Beragama atau Berkeyakinan”. Dalam Kebebasan Beragama atau Berkeyakinan: Seberapa Jauh?, diedit oleh Tore Lindholm, W. Cole Durham Jr., dan Bahia G. Tahzib-Lie, 169-199. Terjemah oleh Rafael Edy Bosko dan M. Rifa'I Abduh. Yogyakarta: Kanisius, 2010.

Lindholm, Tore, W. Cole Durham Jr., Bahia G. Tahzib-Lie, Nazila Ghanea, dan Neni Indriati Wetlesen. "Pengantar". Dalam Kebebasan Beragama atau Berkeyakinan: Seberapa Jauh?, diedit oleh Tore Lindholm, W. Cole Durham Jr., dan Bahia G. Tahzib-Lie, 1-66. Terjemah oleh Rafael Edy Bosko dan M. Rifa’I Abduh. 
Yogyakarta: Kanisius, 2010.

Marzuki, Suparman. Politik Hukum Hak Asasi Manusia. Tanpa kota:

Penerbit Erlangga, 2014.

Muhamadiyah. 100 Tahun Menyinari Negeri. Yogyakarta: Majelis

Pustaka dan Inforganisasii Pimpinan Pusat Muhammadiyah, 2013.

Muhammadiyah, Majelis Tarjih dan Pengembangan Pemikiran

Islam. Tafsir Tematik Al-Qur'an tentang Hubungan Sosial Antar

Umat Beragama. Jakarta: Pustaka SM, 2000.

Nowak, Manfred dan Tanja Vospernik. "Pembatasan-Pembatasan yang Diperbolehkan terhadap Kebebasan Beragama atau Berkeyakinan”. Dalam Kebebasan Beragama atau Berkeyakinan: Seberapa Jauh?, diedit oleh Tore Lindholm, W. Cole Durham Jr., dan Bahia G. Tahzib-Lie, 201-243. Terjemah oleh Rafael Edy Bosko dan M. Rifa'I Abduh. Yogyakarta: Kanisius, 2010.

Pangabean, Syamsul Rizal. "Wahabisme di Indonesia". Makalah

Diskusi Wahhabisme, 10, 2/3/2007.

Rasyid, Daud. "Kata Pengantar". Dalam Topo Santoso. Membumikan

Hukum Pidana Islam: Penegakan Syariat dalam Wacana dan Agenda. Jakarta: Gema Insani Press, 2003.

Roem, Mohamad. "Kata Pengantar: Sejarah Tidak Dapat Dikembalikan”. Dalam Endang Saifuddin. Wawasan Islam: Pokok-Pokok Pikiran tentang Paradigma dan Sistem Islam. Jakarta: Gema Insani Press, 2004.

Shihab, Alwi. Membendung Arus: Respon Gerakan Muhammadiyah terhadap Penetrasi Misi Kristen di Indonesia. Bandung: Mizan, 1998.

Siradj, Said Aqiel. "Ahlussunnah wal Jama'ah di Awal Abad XXI". Dalam Kontroversi Aswaja: Aula Perdebatan dan Reinterpretasi, diedit oleh Imam Baehaqi. Yogyakarta: LKiS, 1999.

Surakarta, Umat Islam (UIS). Surat Ulama Kepada Presiden Ripublik Indonesia 1428/2007M. Surakarta: UIS, 2007.

Turmudi, Endang dan Reza Sihbudi. Islam dan Radikalismedi Indonesia. Jakarta: LIPI Press, 2005.

Wahid, Abdurrahman. Islamku Islam Anda Islam Kita, Agama 
Masyarakat Negara Demokrasi. Jakarta: The Wahid Institute, 2006.

\section{Peraturan Hukum}

Republik Indonesia. Undang-Undang Dasar Negara Republik Indonesia Tahun 1945.

Republik Indonesia. Undang-Undang Nomor 39 Tahun 1999 tentang Hak Asasi Manusia. Lembaran Negara Tahun 1999 Nomor 165, Tambahan Lembaran Negara Nomor 3886.

Republik Indonesia. Undang-Undang Nomor 12 Tahun 2005 tentang Pengesahan International Covenant on Civil and Political Rights. Lembaran Negara Tahun 2005 Nomor 119, Tambahan Lembaran Negara Nomor 4558.

\section{Hasil Wawancara}

Hasil Wawancara dengan KH. Ashari Abta, Pengasuh Pondok Pesantren Krapyak dan Ketua Mustasyar Pengurus Wilayah Nahdlatul Ulama Daerah Istimewa Yogyakarta, Yogyakarta, Juli 2012.

Hasil Wawancara dengan Hamim Ilyas, Anggota Majelis Tarjih Pengurus Pusat Muhammadiyah, Yogyakarta, 29/12/2014. 